Article

\title{
Resource Orchestration in Corporate Social Responsibility Actions: The Case of "Roteiros de Charme" Hotel Association
}

\author{
Luciana Maines da Silva ${ }^{1, *(\mathbb{C}}$ and Paula Maines da Silva ${ }^{2, *}$ \\ 1 Business School, Unisinos University, Av. Unisinos, 950, São Leopoldo 93022-750, Brazil \\ 2 Business School, Universidade Luterana do Brasil-ULBRA, Av. Farroupilha, 8001, Canoas 92425-900, Brazil \\ * Correspondence: lucianamaines@unisinos.br (L.M.d.S.); paula.maines@ulbra.br (P.M.d.S.)
}

Received: 7 May 2020; Accepted: 28 May 2020; Published: 30 May 2020

check for updates

\begin{abstract}
This article aims to identify the factors that generate a competitive advantage, based on resource orchestration, in associated companies in networks with an emphasis on corporate social responsibility (CSR). The "Roteiros de Charme" hotel association was the object of study, deepening the analysis into four hotels and hostels participating in the association, all located in the state of Rio Grande do Sul, Brazil. The method chosen was qualitative comparative analysis (QCA), as it allows for the use of data from a small number of cases. The authors identified that individual CSR strategy, the environmental impact of CSR actions and the structuring of companies' portfolios of resources cover the possible causality and present consistency in the creation of a competitive advantage based on resource orchestration. The analysis of the data showed that the companies associated can structure their portfolio of resources through bundled and leveraged resources for capacity building. The study represents an important managerial contribution since it clarifies what they (resources) are and how the resources of the hotel and the association can be orchestrated for a better financial, social and environmental results. The present study makes a unique theoretical contribution when analyzing the effects on the competitive advantage of CSR actions with the use of the QCA method.
\end{abstract}

Keywords: resource orchestration; corporative social responsibility; hotel association; network; Roteiros de Charme

\section{Introduction}

Both social and environmental concern are present in the actions of a large number of companies [1,2]. Their role is not in doubt, i.e., minimizing environmental effects during the manufacturing or delivery process, while paying attention to social issues [2]. By adopting social responsibility strategies, companies demonstrate that profit is not the primary concern. The concept of corporate social responsibility (CSR) originated in Bowen's [3] seminal book, Social Responsibilities of the Businessman, which defined it as the obligation of entrepreneurs to pursue policies in order to make decisions or follow lines of action that are desirable in terms of the values and goals of society $[1,3]$

The positive impacts of environmental and social actions positively affect a company's financial performance [3], because CSR actions generate value and competitive advantage. However, for this to be achieved, strategic resources and capabilities must be identified and exploited. Management actions are necessary for resources to be structured, bundled and leveraged. These actions are known as "resource orchestration" [4].

Very often, resource orchestration can take place collectively, mainly when companies are organized in a network. As a network is a set of actors connected by different nodes [5], such nodes 
can be established as in the example of Roteiros de Charme, an association that covers independently managed hotels that share some collective actions. The associates are selected because they meet strict criteria regarding quality of service and socio-environmental responsibility. When the organization is networked, the adoption, implementation and maintenance of CSR practices may be by network strategy or as a result of an isomorphic process.

The association between the concepts of resource orchestration and corporate social responsibility has not yet been fully realized. When searching in data bases like Web of Science, Scopus and Google Academy, the authors did not find studies linking it, apart from the fact that, regardless of how CSR occurs, resources and capacities are organized for this purpose.

Based on this assumption, this article seeks to identify the factors that generate competitive advantage, based on resource orchestration, in associated companies in networks with an emphasis on CSR. This work will contribute to the field of interorganizational relations by pointing out what the factors are that generate a competitive advantage for small- and medium-sized companies configured in networks, in addition to contributing to managerial practice by indicating where managers must direct their strategies, within the framework of CSR, to differentiate themselves from competitors.

The present study is organized as follows. First, the concepts of resource orchestration, network and corporate social responsibility are addressed. The empirical method used is described below. Then, the authors present the "Roteiros de Charme" hotel association and the hotels that comprise the study, as well as the results of the analysis of the data. Finally, conclusions are drawn.

\section{Literature Review}

\subsection{Resource Orchestration}

A company's achievement of sustainable competitive advantage and superior economic performance, driven by resources and capabilities controlled by it, is the basis of the resource-based view (RBV) [6]. The RBV provides an explanation of competitive heterogeneity based on the premise that close competitors differ in their resources and capabilities in essential and durable ways [7]. The specific combination of resources for any company will be the result of its history, its strategy and the degree to which the company's strategy fits the external environment, particularly its competitors [8].

Despite the widespread use of the RBV in studies in several areas, some criticisms have been made, especially regarding the lack of information about how resources are used to create a competitive advantage [9]. Responding to criticism, Barney and Arikan [10] stated that studies on the RBV would provide evidence about the actions necessary for the exploitation of resources, which in fact has not been done [10]. To fill this gap, capacity lifecycle studies [7], as well as resource synchronization [10], have been developed. These studies have given rise to the concept of resource orchestration, which refers to the managerial actions necessary for resources to be structured, bundled and leveraged [4]. Thus, we do not lose sight of the creation of competitive advantage, which implies a need for growth [11].

Some studies have tried to reconcile resource orchestration with other themes, but not exhaustively, such as performance measurement systems [12], human resources systems based on commitment [13], the e-commerce adoption process [14], knowledge management [15] and innovation [16].

The orchestration predicts that the unique resources of companies-be they tangible or intangible-must be effectively leveraged, which requires the synchronization of mobilization and coordination mechanisms [17]. Mobilization "provides a plan or vision for capabilities" [4] (p. 1392), while coordination refers to mechanisms that "keep assets co-specialized in the co-alignment of value creation" (p. 28) [18,19].

For the orchestration to be done, the structuring, bundling and leveraging of resources is necessary. Structuring refers to the acquisition, accumulation and disinvestment of resources; bundling involves stabilizing existing capacities, enriching current capabilities and developing new capabilities; leveraging requires a sequence of actions, including mobilization capabilities, to form required capacity configurations, the coordination of integrated capacity configurations and the deployment 
of these configurations with a resource advantage strategy, market opportunity strategy or business strategy [19].

The process of resource orchestration is continuous since internal and external factors also evolve continuously [20]. For this, they should take into account the company's breadth (throughout the company's scope), lifecycle (in various stages of company maturity) and depth (between company levels) [20]. This analysis is required simultaneously in the different stages of resource management (structuring the portfolio of resources, aggregating resources for capacity building, and leveraging configurations of those capabilities to create value for clients and owners), since market feedback concerning customers' needs influences the subprocesses employed in each step or part [10].

When viewed as a process, orchestration helps to structure the company's resource portfolio, aggregate resources to build capabilities, and leverage those resources to create and maintain value for customers and owners [19]. The structuring of the resource portfolio involves the use of processes (acquisition, accumulation and disposal) to obtain the resources that the company will use for bundling and leveraging purposes. Bundling refers to the processes (stabilization, enrichment and pioneering) used to integrate resources to build capacities. Leveraging involves the set of processes (mobilization, coordination and deployment) used to exploit the capabilities in order to take advantage of the opportunities of specific markets and to use resources to create solutions for current and new customers [10].

However, resources are not always readily available. Companies that face resource constraints in some areas can gain a competitive advantage by developing complementary resources in other areas [4], as well as structuring, bundling and leveraging their resources efficiently and effectively to cover their inefficiencies in resource utilization [21]. Besides, they may adopt different growth patterns [11]. One of the growth alternatives is to organize in networks, to identify and develop resources collectively.

\subsection{Network}

A network is a format that has been gaining ground since it provides a competitive differential to the companies that integrate this organizational model. Networks are considered to be a set of actors connected by different links [5], all of which have a common goal. The typology of networks is vast, appearing in different forms, contexts and from diverse cultural expressions, such as the Keiretsu in Japan, family networks in Japanese societies, innovation networks in Silicon Valley, international networks of strategic alliances and cooperation networks in northern Italy [22].

The theme presents different approaches that encompass social, economic and organizational dimensions, as well as different forms of coordination [23]. Moreover, it can still be understood from three approaches, in which the first has the understanding that cooperation networks are a new arrangement aimed at improving organizational performance; the second leads to the process of formation and structuring of cooperative arrangements; and the third, through a broader temporal perspective, understands cooperative interorganizational relationships [24], the last of these being the one used in this article.

Marcon and Moinet [25] developed a conceptual orientation map in which they present four quadrants with main dimensions in which the networks are structured: hierarchy (vertical network), cooperation (horizontal network), contract (formal network) and collusion (informal network) [26]. In vertical networks, the hierarchical structure is taken into account, as greater control is sought-for example, large distribution networks, which adopt this type of network to be closer to the customer or the head office/branch (since the branch follows orders from the parent company and has little autonomy) [26].

In horizontal networks, the companies cooperate in certain actions, but all have independence. This cooperation can occur in relation to technology, information management, the development of new products, the defense of interests, marketing actions, among other aspects. In this model, companies have flexible cooperation, seek to form a learning environment and favor the concentration 
of efforts, without taking away the freedom of action of each member [26]. However, they are complex relationships, because competing actors choose to cooperate within a certain domain, area or sector. Horizontal networks are characterized, therefore, by groupings of companies in a sector or geographic area, which seek, through joint cooperative actions, gains for participating actors and a competitive advantage [27].

In the hotel sector, networking has been used as a way of survival in the market, through the promotion of cooperative actions in the context of collective purchases or even in attracting customers, for example. Best Western is an example of this type of chain, in which each hotel has its own management, but which seeks in the network a way to expand the commercialization of its business. Furthermore, around the world, there are other examples of networks, such as the Versare network in Brazil and OYO Hotels \& Homes in India, among others. From a theoretical standpoint, the networks can be studied through different lenses and with different approaches. A performance that is being analyzed by researchers, although incipient, and also gaining practical space in the networks, in the action of corporate social responsibility, since, collectively, the small and medium networks will generate a positive impact on the environment and local communities.

\subsection{Corporate Social Responsibility}

Concern over social and environmental aspects led companies to take actions to promote some positive social actions, beyond the interests of the company and what is required by law [25]. These actions are recognized as corporate social responsibility (CSR), "a concept whereby companies integrate social and environmental concerns into their operations and their interaction with other stakeholders voluntarily" [28] (p. 7).

Several studies have been developed to understand better the application of this concept in the organizational field, such as the study by Olivo and Mares [29], in which they sought to understand the antecedents and the current state of CSR, the study by Del Baldo [28], in which he analyzed the process used to individualize the relationship between social commitment, social statements and governance of small and medium-sized enterprises, and the analysis of CSR in small and medium enterprises as a strategic function [30]. Finally, CSR can have a high impact at different levels, such as socially (involvement in external social issues, such as education, social inclusion, and generation and volunteering of employees) and economically (addressing employment issues, ethics and environmental issues, including consideration of emissions and waste control, energy use, product lifecycle and sustainable development) [31]. Furthermore, regardless of its impact, it is essential that the company's commitment and knowledge are not confused with help or social assistance.

The commitment to CSR should be aligned with corporate strategies. On the other hand, the company's strategy is influenced by CSR actions. Internal resources, exposure to the international market and institutional pressures affect the differentiation strategy based on CSR at the product level [32]. Integrating social responsibility as part of the organizational strategy requires discussion at different levels. The level of corporate culture contributes to developing values and beliefs and creating a sense of engagement, which is an essential issue in the conception of CSR. The level of innovation helps to transfer and reflect experience in the business routine, leading to the process of learning and innovation. Moreover, the level of civil society is responsible for generating new forms of connection between the organization and environmental needs [33]. The best scenario would be for the strategy to be driven by CSR, thereby ensuring rewards for all company decisions, actions and processes.

To define a CSR strategy, it is necessary to understand the meaning of two elements that are interconnected: on the one hand, that of a responsible corporate citizen, where actions must be legitimized in the direction of incremental and unwritten laws and regulations, affecting corporate culture and, on the other hand, sensemaking and changes in the way people think about CSR, stimulating new relationships involving organizational actors and stakeholders [33].

CSR initiatives in the hotel sector are collective. Large networks such as Hilton [34] and Scandic [35] have demonstrated the networks' environmental concerns, but also the difficulties 
encountered regarding employee behavioral barriers and the high costs involved in seeking energy reduction and $\mathrm{CO} 2$ emissions.

Hospitality studies have sought to understand the phenomenon of CRS in this segment. A study carried out aimed "to explore how senior managers of independent hotels perceive the notion of corporate social responsibility through a holistic analysis of motivations of undertaking both social and environmental initiatives. The findings show that CSR is a dynamic concept involving complex struggles and tradeoffs between fulfilling business objectives, paying heed to personal ethical values and considering cultural norms when making decisions regarding the adoption of a range of environmental and social initiatives" [36] (p. 2468).

Another proposal sought to "identify the determinants of corporate social responsibility (CSR) application in the hotel industry of the Colombian Caribbean. The findings suggest that the degree of CSR application is influenced by the size, age, category, type of contract, financial performance, and level of investment in innovation of the establishments; as well as by the sex, age, level of education, and degree of the directors' autonomy in CSR-related decision-making and their motivations and perceived obstacles" [37] (p. 1).

Recent research has sought to determine the relationship between the implementation of CSR policies and their influence on the Revenue Per Available Room (RevPAR) in Spanish hotels, through marketing variables. According to the researchers "the results of the structural model analyzed reveal that CSR has a discreet but significant role for understanding how marketing variables and RevPAR operate. CSR has a direct impact on RevPAR, but it also influences it indirectly through marketing variables. Therefore, CSR arises as a fundamental strategy to improve the results of the hotel sector in the long term" [38] (p. 1). Nevertheless, European research shows that small hotel companies are also looking for sustainable initiatives. Even more business-oriented companies are implementing social and environmental actions motivated by the pressure of stakeholders (mostly clients) [39]. However, in developing countries, difficulties are still perceived, mainly concerning local communities [40]. The authors highlighted customer skepticism regarding consumers' intention to participate in the clothing reuse programs and intent to revisit hotels [41]. These difficulties often discourage new CSR initiatives.

\section{Materials and Methods}

The objective of this article is to identify the factors that generate a competitive advantage, based on resource orchestration, in associated companies in networks with an emphasis on CSR. The authors carried out qualitative, exploratory research through qualitative comparative analysis (QCA) [42]).

The chosen case was the "Roteiros de Charme" (RC) hotel association, a private, nonprofit entity founded by businessmen in the hotel business [43]. The selection of this association was since the network proposal aims to offer comfort and services concerning nature and social responsibility.

Based on good practice among the members, a code of ethics and environmental conduct was developed, which included information on environmental programs in the area of tourism adopted in several countries, provided by the Tourism Program of Technology, Industry and Economy.

In order to guarantee the main objective of the association, seminars and lectures will stimulate socio-environmental education and the development of activities that will redirect financial resources to employees, as well as help the local community through donations to charities of materials that have not been taken advantage of by the hotel and the cost reduction achieved through the adoption of environmental practices, such as the reduction of waste and material breakdown, water and energy saving, waste reuse and recycling [43].

Roteiros de Charme has 73 small and medium-sized hotels, hostels and ecological refuges in 16 Brazilian states and 64 tourist destinations, located from the north to the south of Brazil [44]. For convenience, only the network members located in the state of Rio Grande do Sul were analyzed. An exception occurred with the Estalagem St Hubertus, where it was not possible to conduct an interview due to the manager not being available. Table 1 details each of them. 
Table 1. Characterization of hotels, hostels and ecological refuges.

\begin{tabular}{|c|c|c|c|}
\hline Company & Location & $\begin{array}{c}\text { Date of } \\
\text { Association }\end{array}$ & Features \\
\hline $\begin{array}{l}\text { Estalagem St } \\
\text { Hubertus [45] }\end{array}$ & Gramado/RS & 1998 & $\begin{array}{l}\text {-Category: Topázio Imperial (classification given by } \\
\text { the hotel association in which a hotel is well equipped, } \\
\text { with adequate facilities and social spaces, high-level } \\
\text { services, style and exquisite decoration); } \\
\text {-Environmental conduct in which it aims at the use of } \\
\text { alternative energy such as solar energy for heating the } \\
\text { water; substation and own generator; the presence of } \\
\text { sensors in the corridors; use of low-energy lamps; PVC } \\
\text { and double glass frames, capable of maintaining } \\
\text { energy in the environment; implementation of } \\
\text { environmental practices such as the use of a sauna at a } \\
\text { guest's request; power switches; bath towel changing } \\
\text { system, allowing guests to participate in the program; } \\
\text { moderate use of water; use of recyclable paper; } \\
\text { awareness of the whole team for actions and simple, } \\
\text { day-to-day care. }\end{array}$ \\
\hline $\begin{array}{l}\text { Pousada Cravo } \\
\text { e Canela [46] }\end{array}$ & Canela/RS & 2005 & $\begin{array}{l}\text {-Category: Água Marinha (classification given by the } \\
\text { hotel association in which a hotel whose decoration, } \\
\text { good service value the local environment and } \\
\text { characteristics); } \\
\text {-Built-in a historic mansion that belonged to a former } \\
\text { governor of the state of RS. }\end{array}$ \\
\hline $\begin{array}{c}\text { Parador Casa } \\
\text { da Montanha } \\
\text { [47] }\end{array}$ & Cambará do Sul/RS & 2006 & $\begin{array}{l}\text {-Category: Pedra Ametista (classification given by the } \\
\text { hotel association in which a hotel is located in an } \\
\text { ecological paradise, where the unpretentious service } \\
\text { and the decoration maintain identity with the region); } \\
\text {-The hotel is located on a farm near the Aparados da } \\
\text { Serra National Park and the Itaimbezinho Canyon, in } \\
\text { the Campos de Cima da Serra, and has the ecovillage } \\
\text { concept, in which guests stay in thermal huts inspired } \\
\text { by African lodges. }\end{array}$ \\
\hline $\begin{array}{l}\text { Estalagem La } \\
\text { Hacienda [48] }\end{array}$ & Gramado/RS & 2009 & $\begin{array}{c}\text {-Category: Topázio Imperial (classification given by } \\
\text { the hotel association in which a hotel is well equipped, } \\
\text { with adequate facilities and social spaces, high-level } \\
\text { services, style and exquisite decoration); } \\
\text {-It has only six chalets and is situated in an area of } \\
70 \text { hectares with preserved forest, waterfalls, streams } \\
\text { and lakes. }\end{array}$ \\
\hline $\begin{array}{l}\text { Pousada do } \\
\text { Engenho [49] }\end{array}$ & $\begin{array}{c}\text { São Francisco de } \\
\text { Paula/RS }\end{array}$ & 2011 & $\begin{array}{l}\text {-Category: Pedra Esmeralda (classification given by } \\
\text { the hotel association in which a hotel has a privileged } \\
\text { location, generous spaces, facilities and services that } \\
\text { meet the standards of the traditional international } \\
\text { hotel industry); } \\
\text {-The huts were built to favour integration with the } \\
\text { green surroundings. } \\
\text {-Actions are developed aimed at taking care of the of } \\
\text { constructions until the treatment of effluents, such as } \\
\text { the used water that comes almost entirely from a slope } \\
\text { that is on the property. Effluents are treated locally; } \\
\text { there is the use of organic products, which are planted } \\
\text { on the property; separation of garbage and compost } \\
\text { from organic waste; use of a saline system instead of } \\
\text { chlorine for the pool water and hot tub; and care for } \\
\text { the property without the use of chemicals. }\end{array}$ \\
\hline
\end{tabular}

Data collection was done through in-depth interviews, based on a semi-structured script (Appendix A) based on theory, with the leading managers of four of the five hotels, as shown in Table 2. The authors conducted interviews between November and December 2016, at the headquarters of the companies, and the interviews lasted (on average) for $60 \mathrm{~min}$. 
Table 2. Data of interviewees.

\begin{tabular}{ccc}
\hline Interviewee & Company & Position \\
\hline E1 & Pousada Cravo \& Canela-Canela/RS & Owner \\
\hline E2 & Parador Casa da Montanha-Cambará do Sul/RS & Quality manager \\
\hline E3 & Estalagem La Hacienda-Gramado/RS & Manager \\
\hline E4 & Pousada do Engenho-São Francisco de Paula/RS & Administrator \\
\hline
\end{tabular}

The authors carried out data triangulation, through interviews with the main hotel managers, in addition to information from the association's websites and each hotel. Finally, the interviews were conducted in person at the headquarters of each hotel, with the objective of observing CSR practices in loco. Finally, to meet the research objectives, the number of interviews provided the necessary support to run the QCA system, meeting the research objectives.

The results of the data collection led to qualitative comparative analysis (QCA) [42]. This method was chosen because it allows for causal inferences, characteristics and context based on a small number of cases [42]. The QCA is used based on the binary logic of Boolean algebra and potentiates the number of comparisons that can be made in the cases studied [50].

The QCA method foresees the fulfilment of stages for its development [51], which were as follows: (a) summarizing the data-synthetically describing the cases, presenting the similarities through a table of observations called a "truth table", where combinations of values of the variables were made individually and together, verifying the consistencies and contradictions and assigning values to the binary variables (zero for absent condition and one for present condition); (b) verification of the coherence between the data, which makes it possible to verify contradictions in the cases analyzed; (c) the use of theories to corroborate or refute existing theories and assumptions; (d) testing new ideas or assumptions that are not incorporated in the existing theory, confirming or not a result in the selected cases; and finally, (e) elaboration of new assumptions or theories, from the table of observations, from which it is possible to obtain data for new theoretical arguments.

The analysis procedure started by identifying the conditions of interest, in which the absence (zero) or presence (one) of the causal conditions were observed (detailed in Table 3). The development of each condition of interest was based on the theory on the subject and the research objective. After the conditions of interest were identified, the truth-table was constructed, which reflected the aspects raised in the conditions of interest (" 1 " present, " 0 " absent and " $X$ " not observed) for each aspect in relation to each case [48]. The authors ran the software using the abbreviations of the terms in Portuguese.

Table 3. Conditions of interest.

\begin{tabular}{ccc}
\hline Condition (Code) & Rational Analysis & Dichotomy \\
\hline $\begin{array}{c}\text { Creation of resource-based } \\
\text { competitive advantage } \\
\text { (VAN) }\end{array}$ & $\begin{array}{c}\text { When there is a specific combination } \\
\text { of features and capabilities. }\end{array}$ & $\begin{array}{c}\text { (1) Presence of specific resources and } \\
\text { capabilities; }\end{array}$ \\
$\begin{array}{c}\text { (0) Absence of specific resources and } \\
\text { capabilities. }\end{array}$ \\
$\begin{array}{c}\text { Leveraging enterprise-only } \\
\text { resources (ALA) }\end{array}$ & $\begin{array}{c}\text { When the mechanisms of } \\
\text { mobilization and coordination are } \\
\text { synchronized. }\end{array}$ & $\begin{array}{c}\text { (1) Presence of mobilization and } \\
\text { coordination mechanisms; }\end{array}$ \\
$\begin{array}{c}\text { Structuring the enterprise } \\
\text { resource portfolio (EST) }\end{array}$ & $\begin{array}{c}\text { When resources to build capabilities } \\
\text { are aggregated and leveraged. }\end{array}$ & $\begin{array}{c}\text { (1) Presence of exclusive resources; } \\
\text { condination mechanisms. }\end{array}$ \\
\hline $\begin{array}{c}\text { Reciprocity in the } \\
\text { interorganizational } \\
\text { relationship (REC) }\end{array}$ & $\begin{array}{c}\text { When there is the mutuality of } \\
\text { benefits acquired by the hotel } \\
\text { association, based on cooperation. }\end{array}$ & $\begin{array}{c}\text { (1) Presence of reciprocity; } \\
\text { (0) Absence of reciprocity. }\end{array}$ \\
\hline
\end{tabular}


Table 3. Cont.

\begin{tabular}{|c|c|c|}
\hline Condition (Code) & Rational Analysis & Dichotomy \\
\hline $\begin{array}{l}\text { Collective strategies for } \\
\text { corporate social } \\
\text { responsibility (COL_RSC) }\end{array}$ & $\begin{array}{l}\text { The influence of the hotel } \\
\text { association on the collective } \\
\text { strategies of small companies within } \\
\text { the framework of CSR. }\end{array}$ & $\begin{array}{c}\text { (1) Presence of hotel association influence } \\
\text { within CSR; } \\
\text { (0) Absence of hotel association influence } \\
\text { within the framework of CSR. }\end{array}$ \\
\hline $\begin{array}{l}\text { Individual Strategies for } \\
\quad \text { Corporate Social } \\
\text { Responsibility (IND_RSC) }\end{array}$ & $\begin{array}{l}\text { The influence of individual small } \\
\text { business strategies in the hotel } \\
\text { association within the framework of } \\
\text { CSR. }\end{array}$ & $\begin{array}{l}\text { (1) Presence of small business influence } \\
\text { within CSR; } \\
\text { (0) Lack of influence of small companies } \\
\text { in the context of CSR. }\end{array}$ \\
\hline $\begin{array}{l}\text { Social impact of CSR } \\
\text { actions (SOC) }\end{array}$ & $\begin{array}{l}\text { When there is involvement in } \\
\text { external social issues, such as } \\
\text { education, social inclusion, } \\
\text { generation and volunteering of } \\
\text { employees. }\end{array}$ & $\begin{array}{l}\text { (1) Presence of social actions; } \\
\text { (0) Absence of social actions. }\end{array}$ \\
\hline $\begin{array}{l}\text { The economic impact of } \\
\text { CSR actions (ECO) }\end{array}$ & $\begin{array}{l}\text { When there is involvement in issues } \\
\text { related to jobs, ethical training } \\
\text { standards and product value. }\end{array}$ & $\begin{array}{l}\text { (1) Presence of economic actions; } \\
\text { (0) Absence of economic actions. }\end{array}$ \\
\hline $\begin{array}{l}\text { Impact on the environment } \\
\text { of CSR actions (AMB) }\end{array}$ & $\begin{array}{l}\text { When there is involvement in issues } \\
\text { such as emissions and waste control, } \\
\text { energy use, product lifecycle and } \\
\text { sustainable development. }\end{array}$ & $\begin{array}{l}\text { (1) Presence of environmental actions; } \\
\text { (0) Absence of environmental actions. }\end{array}$ \\
\hline
\end{tabular}

The following section presents a case study of the Roteiros de Charme hotel association and a discussion of the results.

\section{Results}

In order to start the analysis, it was necessary to tabulate the data in an Excel spreadsheet, to create the truth table and export it to the fs/QCA software. From the generated software data, two results were obtained, a complex solution and an intermediate solution. Based on the two solutions, a synthesis table (Table 4) was developed with the main results obtained in each one.

Table 4. Synthesis of the results of the two solutions.

\begin{tabular}{|c|c|c|c|c|}
\hline Solution & Causal Conditions * & Raw Coverage & Unique Coverage & Consistency \\
\hline \multirow{2}{*}{ Complex } & $\begin{array}{c}\mathrm{ALA}^{*} \mathrm{EST}^{*} \sim \mathrm{REC}^{*} \sim \mathrm{COL}_{\mathrm{C}} \mathrm{RSC}^{*} \sim \mathrm{SOC}^{*} \sim \\
\mathrm{ECO}^{*} \mathrm{AMB}\end{array}$ & 0.5 & 0.5 & 1 \\
\hline & 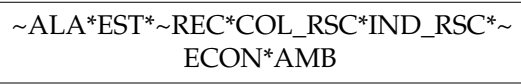 & 0.5 & 0.5 & 1 \\
\hline \multirow{2}{*}{ Intermediate } & $\begin{array}{c}\mathrm{ALA}^{*} \mathrm{EST}^{*} \sim \mathrm{REC}^{*} \sim \mathrm{COL} \_\mathrm{RSC}^{*} \sim \mathrm{SOC}^{*} \sim \\
\mathrm{ECO}^{*} \mathrm{AMB}\end{array}$ & 0.5 & 0.5 & 1 \\
\hline & $\begin{array}{c}\sim \mathrm{ALA}^{*} \mathrm{EST}^{*} \sim \mathrm{REC}^{*} \mathrm{COL} \_\mathrm{RSC} \mathrm{IND}^{*} \mathrm{RSC} \mathrm{C}^{*} \sim \\
\mathrm{ECON}^{*} \mathrm{AMB}\end{array}$ & 0.5 & 0.5 & 1 \\
\hline
\end{tabular}

* In Boolean algebra the symbol "+" means "OR" and the symbol "*" means "AND", " " deals with the negation of the data.

Table 4 presents, from the two solutions, the causal configurations with more excellent coverage, indicating those that can effectively influence the creation of a competitive advantage based on resources (VAN). It was observed that, in both the complex and the intermediate solutions, there are two sets of causal conditions covering $50 \%$ each. The first is the presence of leverage in the company's unique resources (ALA) and the presence of the structuring of the company's resource portfolio (EST), as well as a lack of reciprocity in the interorganizational relationship (REC), the absence of collective corporate social responsibility strategies (COL_RSC), a lack of social impact of CSR actions (SOC), a lack of economic impact of CSR actions (ECO) and the presence of an environmental impact of CSR actions (AMB). The second one has the presence of leverage of the company's exclusive resources (ALA), 
the presence of the structuring of the company's resource portfolio (EST), the absence of reciprocity in the interorganizational relationship (REC), the presence of collective corporate social responsibility strategies (COL_RSC), the presence of individual corporate social responsibility strategies (IND_RSC), a lack of economic impact of CSR actions (ECO) and the presence of an environmental impact of CSR actions (AMB).

In the sequence, the authors analyzed the presence and/or absence of variables necessary for the effect, through the command necessary condition. With this, the following results were generated (Figure 1).

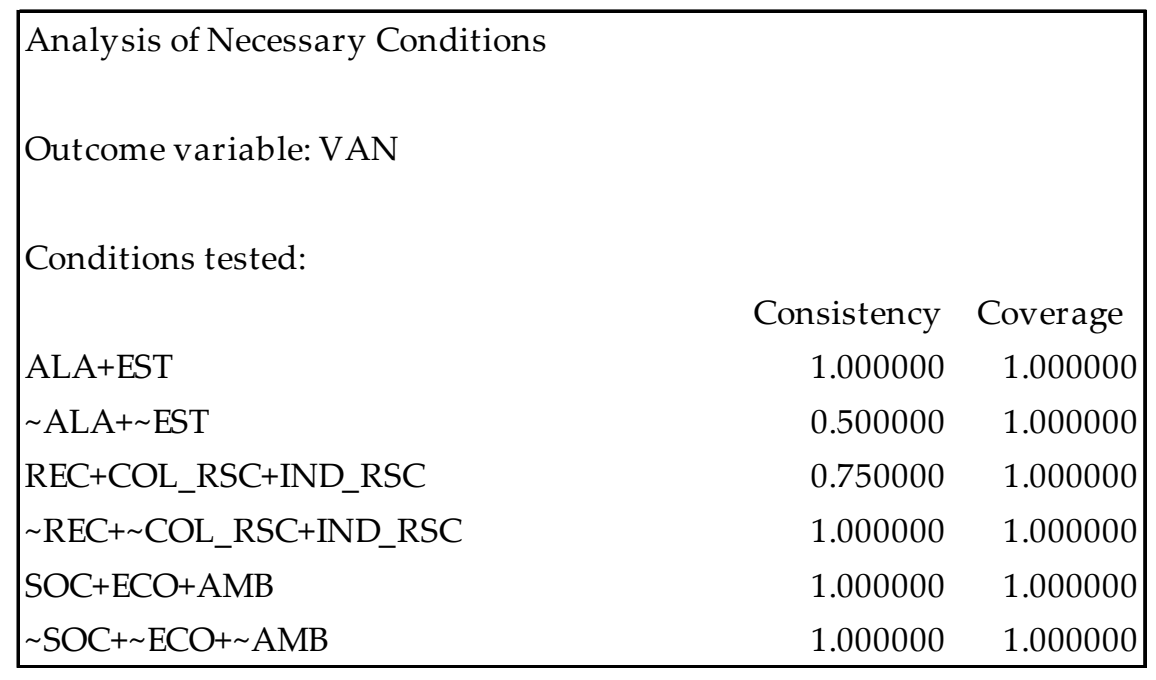

Figure 1. Necessary conditions analysis.

Based on the results of Figure 1, it is verified that the present causal variables "leverage" and "structuring" present a consistency of 1 and coverage of $100 \%$. Moreover, the absence of "reciprocity" or "collective strategies" or "individual strategies", the presence of "social impact" or "economic impact" or "environmental impact" and the absence of "social impact" or "economic impact" or "environmental impact" have the same consistency and coverage. These variables present a high degree of influence in the creation of competitive advantage based on resources.

Then, coincidence analysis was performed, testing the variables of the necessary conditions. The results of coincidences with a percentage higher than 50\% are shown in Figure 2.

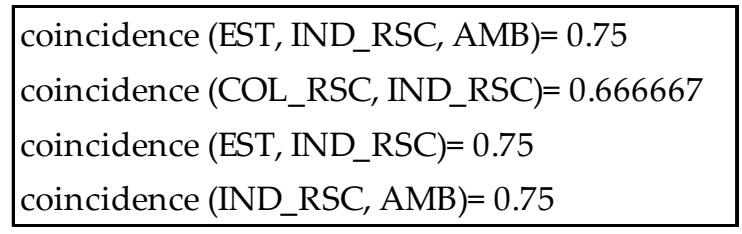

Figure 2. Coincidence analysis-Round 1.

The analysis, according to Figure 2, showed a $67 \%$ coincidence for the causal variables "collective strategies" and "individual strategies". Moreover, it showed a 75\% coincidence between the causal variables "structuring", "individual strategies" and "environmental impact", as well as the same percentage for "structuring" and "individual strategies" and also for "individual strategies". One can see, therefore, that these combinations demonstrate a strong possibility of a causal relationship with the creation of resource-based competitive advantage.

A new coincidence test was performed considering only the present variables IND_RSC,COL_RSC, $\mathrm{AMB}$ and EST. Figure 3 presents these results: 


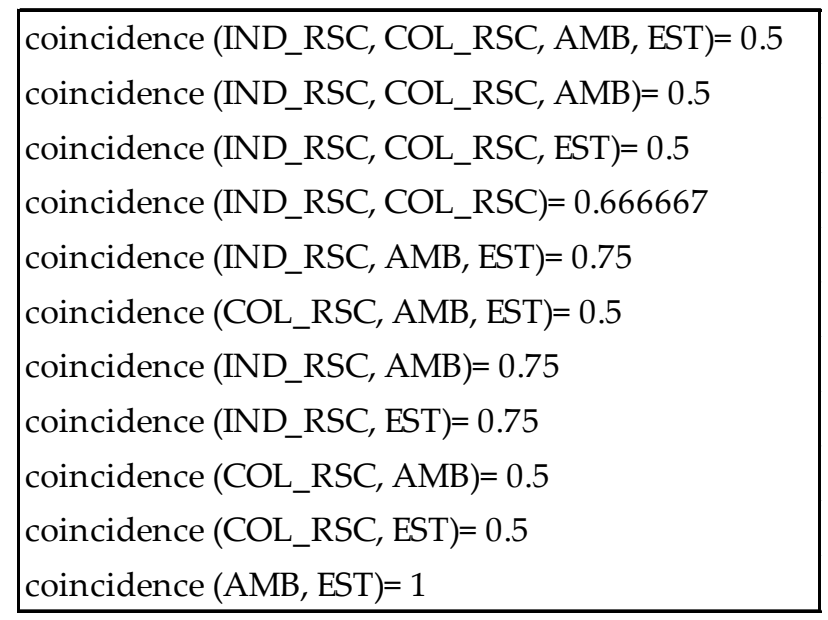

Figure 3. Coincidence analysis-Round 2.

In this analysis, the most significant coincidence $(100 \%)$ occurred in the combination "environmental impact" and "structuring". In cases where the coincidence was $75 \%$, the combinations "individual strategies" and "environmental impact" and "structuring", "individual strategies" and "environmental impact" and "individual strategies and structuring" occurred.

When conducting another round, this time excluding "collective strategies", the authors obtained the same result when considering only the variables IND_RSC, AMB and EST (Figure 4).

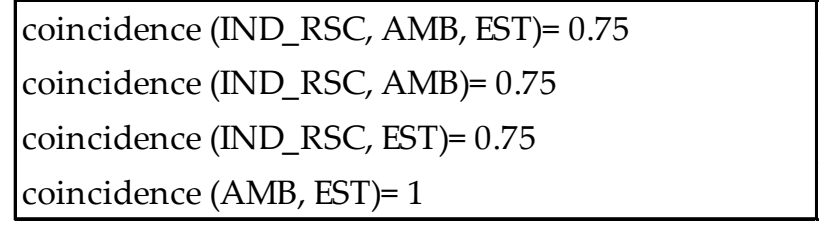

Figure 4. Matching analysis-Round 3.

Finally, the authors conducted a test of the analysis of necessary conditions, working the variables with binomials (Figure 5).

\begin{tabular}{|lll|}
\hline Conditions tested: & & \\
& Consistency & Coverage \\
IND_RSC + AMB & 1.000000 & 1.000000 \\
IND_RSC + EST & 1.000000 & 1.000000 \\
AMB + EST & 1.000000 & 1.000000 \\
\hline
\end{tabular}

Figure 5. Analysis of the necessary conditions.

From these results, the expression that best describes the causal relationship between the three reduced variables, namely individual CSR strategies, the environmental impact of CSR actions and structuring the company's portfolio of resources, is (IND_RSC + AMB + EST) $\rightarrow$ VAN. It means that individual CSR strategies plus the environmental impact of CSR actions plus the structuring of the company's resource portfolio cover $100 \%$ of possible causality as well as $100 \%$ consistency in creating a competitive advantage based on resource orchestration.

The environmental concern was the motivation for some entrepreneurs to meet and create the hotel association Roteiros de Charme (RC). Although CSR represents a high social, economic and environmental impact [26], the data analysis found that hotels and inns in the Rio Grande do Sul base their actions on environmental aspects, such as alternative energy use and the treatment of effluents. 
The commitment alignment of CSR and the corporate strategy is verified in data analysis [31], within the associated companies or the network. However, the authors identified that, despite the environmental concern being the motivation in the creation of Roteiros de Charme, CSR initiatives and strategies are developed individually by each member.

Roteiros de Charme is understood as a cooperative interorganizational relationship [24], motivated by legitimacy-that is, organizations' intentions to improve their reputation, image and prestige [52]. This type of setting generates gains through learning and innovation, through the sharing of ideas and experiences among the associates and the innovative actions developed jointly by the participants [53-55].

It is not only necessary to identify their strategic resources, but the structuring, grouping and leveraging of these resources through management actions is necessary [4]. The analysis of the data showed that the companies associated with the hotel association could structure the portfolio of resources, through bundling and leveraging resources for capacity building.

\section{Discussion}

Obtaining a competitive advantage is essential for the economic sustainability of organizations. A networking strategy is adopted by organizations improving their reputation, image and prestige. The orchestration of strategic resources, aligned with strategies of corporate social responsibility, can be generators of competitive advantage.

From the QCA method, the authors perceived the presence of three factors internal to the company: leverage of the company's exclusive resources (ALA); structuring of the company's resource portfolio (EST); and environmental impact of CSR actions (AMB). Concerning the external factors, reciprocity in the interorganizational relationship (REC) and collective strategies of corporate social responsibility (COL_RSC), one can perceive the absence of these. Thus, from this context, the authors have the first proposition:

Proposition 1. The participation of the company in a hotel association does not influence its CSR actions.

Despite the hotel association's motivation, collective strategies have not been shown to generate a competitive advantage. Our findings are reinforced by authors such as Ireland et al. [56] and, more recently, Macaulay et al. [57], who discussed the positioning of companies in a network. Thus, the further away from the nucleus, the smaller the influence. The composition of the Roteiros de Charme hotel association may, in the end, have little influence on its participants. This aspect can be analyzed by the hotel association managers to guide their future strategies.

Although the CSR actions are positively associated with past financial performance, as well as future financial performance [58], the analysis of both causal conditions reveals the lack of an economic impact due to CSR actions. Thus, the authors offer the second proposition:

Proposition 2. The resource orchestration focused on CSR actions does not generate a positive economic impact on associated companies.

This is a point that needs attention since several studies reaffirm that CSR actions are responsible for positive (even if not above average) financial results [40-59].

The authors also perceive the absence, in both causal conditions, of reciprocity in the interorganizational relationship (REC). Even the formation of the Roteiros de Charme hotel association has, as its primary objective, the offer of comfort and services concerning nature and social responsibility, and hotel association participants do not realize that hotel association management contributes significantly. This analysis leads us to the third proposition:

Proposition 3. There is no reciprocity in the interorganizational relationship focused on CSR actions. 
Roteiros de Charme was created to link small and medium businesses by a common goal, which is to provide lodging services while using CSR practices. However, the authors highlight that there is no synergy between the companies and the hotel association. This can only happen through the synergy - the combination of resources and the skills of a group of people and organizations [60].

Finally, when the authors investigated the resource orchestration in the lower level of the analysis, that is, with the participants of the hotel association, the orchestration performed by the hotel association was not perceived. Thus, the authors offer the fourth proposition:

Proposition 4. Resource orchestration is performed only by hotel association participants.

The research highlighted that individual CSR strategy, the environmental impact of CSR actions and the structuring of companies' portfolios of resources can leverage a competitive advantage based on resource orchestration.

\section{Conclusions}

Since the purpose of this article was to identify the factors that generate a competitive advantage, based on resources, in associated companies in a network with an emphasis on CSR, the Roteiros de Charme association was chosen as the object of study. The analysis was carried out in four hotels and hostels participating in the hotel association, located in the state of Rio Grande do Sul. The hotel association has a strong connection with corporate social responsibility, especially with regard to environmental aspects. When analyzing the factors that generated a competitive advantage, it was identified that individual CSR strategies, plus the environmental impact of CSR actions, plus the structuring of the company's resource portfolio are consistent factors in the creation of a resource-based competitive advantage. Based on this analysis, the authors made some propositions.

Our study represents an important managerial contribution. The research presents that, for a better financial, social and environmental result, the specific resources of the hotels and the association can be orchestrated. Moreover, this research contributes to the CSR discussion and strategies for CSR, using the QCA method.

\section{Limitations and Avenues for Future Research}

Our research has some limitations. The first one is the small number of companies analyzed. The companies were selected from a specific area of Brazil (the state of Rio Grande do Sul). The authors believe that in loco observation gives an important contribution to QCA analyses. Another limitation is that the survey was conducted in 2016.

Based on our findings, and also the limitations of this research, further studies are possible. First, the authors suggest the expansion of the analysis to the whole hotel association. Other networks that have an emphasis on CSR can be analyzed. A more in-depth search of the orchestration carried out by the hotel association management, alongside with the orchestration performed by each participant in the hotel association, could be carried out. Finally, an alternative is to evaluate the orchestration of the hotel association as a whole, through its relationship processes, such as knowledge mobility, innovation appropriation and network stability [61].

Author Contributions: All authors contributed equally to this paper. All authors have read and agreed to the published version of the manuscript.

Funding: This research received no external funding.

Conflicts of Interest: The authors declare no conflicts of interest.

\section{Appendix A : Semi-Structured Script}

1. Who is the hotel most often in and out of the chain?

2. How does the hotel define its CSR strategies? 
3. How does the relationship with the actors (identified in item 1) influence CSR strategies?

4. Is there any type of business relationship that ended up having a different relational focus? Example: Some customer who became a supplier or some customer who became a friend.

5. Does the hotel relate to or benchmark hotels in other countries regarding CSR practices?

6. Does the hotel maintain a relationship with only the same suppliers? With the same customers? And with the same institutions? (see actors identified in item 1 of the first block and they will enter the question)

7. Do relations with external actors affect the priorities of practices focused on social, environmental and economic aspects?

8. When the hotel thinks about developing a CSR action, is there a need for any consultation/exchange of ideas with external stakeholders?

9. Does the intensity of the relationship with these actors interfere with the opinion they provide for the development of CSR strategies that the hotel develops?

10. How long has the hotel been in contact with its suppliers?

11. How long have the hotel's main customers been customers?

12. How long has the hotel been in contact with institutions?

13. And does the time of relationship with these actors interfere with the opinion they provide for the development of CSR strategies that the hotel develops?

\section{References}

1. Acquier, A.; Gond, J.P.; Pasquero, J. Rediscovering Howard R. Bowen's legacy: The unachieved agenda of social responsibilities of the businessman and its continuous relevance. Bus. Soc. 2011, 50, 607-646. [CrossRef]

2. Klassen, R.D.; McLaughlin, C.P. The impact of environmental management on firm performance. Manag. Sci. 1996, 42, 1199-1214. [CrossRef]

3. Bowen, H.R. Social Responsibilities of the Businessman; Harper \& Row: New York, NY, USA, 1953.

4. Sirmon, D.G.; Hitt, M.A.; Ireland, R.D.; Gilbert, B.A. Resource orchestration to create competitive advantage breadth, depth, and life cycle effects. J. Manag. 2011, 37, 1390-1412.

5. Borgatti, S.P.; Foster, P.C. The network paradigm in organizational research: A review and typology. J. Manag. 2003, 29, 991-1013.

6. Barney, J. Firm resources and sustained competitive advantage. J. Manag. 1991, 17, 99-120. [CrossRef]

7. Helfat, C.; Peteraf, M. The dynamic resource-based view: Capability lifecycles. Strateg. Manag. J. 2003, 24, 997-1010. [CrossRef]

8. Black, J.A.; Boal, K.B. Strategic resources: Traits, configurations and paths to sustainable competitive advantage. Strateg. Manag. J. 1994, 15, 131-148. [CrossRef]

9. Priem, R.L.; Butler, J.E. Is the resource-based 'view' a useful perspective for strategic management research? Acad. Manag. Rev. 2001, 26, 22-40.

10. Sirmon, D.G.; Hitt, M.A.; Ireland, R.D. Managing firm resources in dynamic environments to create value: Looking inside the black box. Acad. Manag. Rev. 2007, 32, 273-292. [CrossRef]

11. Wright, M.; Stigliani, I. Entrepreneurship and growth. Int. Small Bus. J. 2013, 31, 3-22. [CrossRef]

12. Koufteros, X.; Verghese, A.J.; Lucianetti, L. The effect of performance measurement systems on firm performance: A cross-sectional and a longitudinal study. J. Oper. Manag. 2014, 32, 313-336. [CrossRef]

13. Chadwick, C.; Super, J.F.; Kwon, K. Resource orchestration in practice: CEO emphasis on SHRM, commitment-based HR systems, and firm performance. Strateg. Manag. J. 2015, 36, 360-376. [CrossRef]

14. Cui, M.; Pan, S.L. Developing focal capabilities for e-commerce adoption: A resource orchestration perspective. Inf. Manag. 2015, 52, 200-209. [CrossRef]

15. Lanza, A.; Simone, G.; Bruno, R. Resource orchestration in the context of knowledge resources acquisition and divestment. The empirical evidence from the Italian "Serie A" football. Eur. Manag. J. 2016, 34, 145-157. [CrossRef] 
16. Wowak, K.D.; Craighead, C.W.; Ketchen, D.J., Jr.; Hult, G.T.M. Toward a 'Theoretical Toolbox' for the supplier-enabled fuzzy front end of the new product development process. J. Supply Chain Manag. 2016, 52, 66-81. [CrossRef]

17. Chirico, F.; Sirmon, D.G.; Sciascia, S.; Mazzola, P. Resource orchestration in family firms: Investigating how entrepreneurial orientation, generational involvement, and participative strategy affect performance. Strateg. Entrep. J. 2011, 5, 307-326. [CrossRef]

18. Helfat, C.; Finkelstein, S.; Mitchell, W.; Peteraf, M.; Singh, H.; Teece, D.; Winter, S. Dynamic Capabilities: Understanding Strategic Change in Organizations; Blackwell Publishers: Hoboken, NJ, USA, 2007.

19. Hitt, M.A.; Ireland, R.D.; Sirmon, D.G.; Trahms, C.A. Strategic entrepreneurship: Creating value for individuals, organizations, and society. Acad. Manag. Perspect. 2011, 25, 57-75.

20. Ketchen, D.J.; Wowak, K.D.; Craighead, C.W. Resource gaps and resource orchestration shortfalls in supply chain management: The case of product recalls. J. Supply Chain Manag. 2014, 50, 6-15. [CrossRef]

21. Wales, W.J.; Patel, P.C.; Parida, V.; Kreiser, P.M. Nonlinear effects of entrepreneurial orientation on small firm performance: The moderating role of resource orchestration capabilities. Strateg. Entrep. J. 2013, 7, 93-121. [CrossRef]

22. Castells, M. A Era da Informação: Economia, Sociedade e Cultura; Paz e Terra: São Paulo, Brazil, 1999.

23. Grandori, A.; Soda, G. Inter-firm networks: Antecedents, mechanisms and forms. Organ. Stud. 1995, 16, 183-214. [CrossRef]

24. Martes, A.C.B.; Bulgacov, S.; Nascimento, M.R.D.; Gonçalves, S.A.; Augusto, P.M. Fórum-redes sociais e interorganizacionais. Rev. Adm. Empresas 2006, 46, 10-15. [CrossRef]

25. Marcon, M.; Moinet, N. La Stratégie-Réseau; Éditions Zéro Heure: Paris, France, 2000.

26. Balestrin, A.; Vargas, L.M. A Dimensão Estratégica das Redes Horizontais de PMEs: Teorizações e Evidências. Available online: https://www.scielo.br/scielo.php?pid=S1415--65552004000500011\&script=sci_abstract\& tlng=pt (accessed on 23 March 2020).

27. Carvalho, M.M.; Lautindo, F.J.B. Estratégia competitiva: Dos conceitos à implementação. 2. ed. São Paulo: Atlas, 2010. Corporate social responsibility: Strategic implications. J. Manag. Stud. 2006, 43, 1-18.

28. Dahlsrud, A. How corporate social responsibility is defined: An analysis of 37 definitions. Corp. Soc. Responsib. Environ. Manag. 2008, 15, 1-13. [CrossRef]

29. Olivo, H.C.; Mares, A.I. Retrospectiva de la responsabilidad social empresarial a través del desarrollo del pensamiento econômico. Revista Universo Contábil. FURB 2009, 5, 116-133.

30. Del Baldo, M. Corporate social responsibility and corporate governance in Italian SMEs: The experience of some 'spirited businesses. J. Manag. Gov. 2012, 16, 1-36. [CrossRef]

31. Coppa, M.; Sriramesh, K. Corporate Social Responsibility among SMEs in Italy. Available online: https: //pdfs.semanticscholar.org/8814/f62366ae787092b6a3849e8cac7e6d20572e.pdf (accessed on 15 March 2020).

32. Andriof, J.; McIntosh, M. Perspectives on Corporate Citizenship; Greenleaf Publishing: Abingdon, England, 2001.

33. Cruz, L.B.; Boehe, D.M.; Ogasavara, M.H. CSR-based differentiation strategy of export firms from developing countries: An exploratory study of the strategy tripod. Bus. Soc. 2015, 54, 723-762. [CrossRef]

34. Hanke, T.; Stark, W. Strategy development: Conceptual framework on corporate social responsibility. J. Bus. Ethics 2009, 85, 507-516. [CrossRef]

35. Bohdanowicz, P.; Zientara, P.; Novotna, E. International hotel chains and environmental protection: An analysis of Hilton's we care! programme (Europe, 2006-2008). J. Sustain. Tour. 2011, 19, 797-816. [CrossRef]

36. Abaeian, V.; Khong, K.W.; Yeoh, K.K.; McCabe, S. Motivations of undertaking CSR initiatives by independent hotels: A holistic approach. Int. J. Contemp. Hosp. Manag. 2019, 31, 2468-2487. [CrossRef]

37. Miranda, D.D.P.; Ortiz, J.A.; Cardona, J.R. Determinants of CSR Application in the Hotel Industry of the Colombian Caribbean. Sustainability 2019, 11, 5045. [CrossRef]

38. Romero, J.M.M.; Mogollón, J.M.H.; Campón-Cerro, A.M.; Fernández, J.A.F. Corporate Social Responsibility in Hotels: A Proposal of a Measurement of its Performance through Marketing Variables. Sustainability 2020, 12, 2961. [CrossRef]

39. Bohdanowicz, P.; Zientara, P. Corporate social responsibility in hospitality: Issues and implications. A case study of Scandic. Scand. J. Hosp. Tour. 2008, 8, 271-293. [CrossRef]

40. Font, X.; Garay, L.; Jones, S. Sustainability motivations and practices in small tourism enterprises in European protected areas. J. Clean. Prod. 2016, 137, 1439-1448. [CrossRef] 
41. Anderson, W. Linkages between tourism and agriculture for inclusive development in Tanzania: A value chain perspective. J. Hosp. Tour. Insights 2018, 1, 168-184. [CrossRef]

42. Rahman, I.; Park, J.; Chi, C.G.Q. Consequences of 'greenwashing.' Consumers' reactions to hotels' green initiatives. Int. J. Contemp. Hosp. Manag. 2015, 27, 1054-1081. [CrossRef]

43. Ragin, C.C.; Shulman, D.; Weinberg, A.; Gran, B. Complexity, generality, and qualitative comparative analysis. Field Methods 2003, 15, 323-340. [CrossRef]

44. Roteiros de Charme. Available online: http://http://www.roteirosdecharme.com (accessed on 2 January 2017).

45. Estalagem St. Hubertus. Available online: http://www.sthubertus.com (accessed on 2 January 2017).

46. Pousada Cravo e Canela. Available online: http://www.pousadacravoecanela.com (accessed on 2 January 2017).

47. Parador Casa Da Montanha. Available online: http://www.paradorcasadamontanha.com (accessed on 2 January 2017).

48. Estalagem La Hacienda. Available online: http://www.lahacienda.com (accessed on 2 January 2017).

49. Pousada Do Engenho. Available online: http://www.pousadadoengenho.com (accessed on 2 January 2017).

50. Ragin, C.C. The Comparative Method: Moving Beyond Qualitative and Quantitative Strategies; University of California Press: Berkeley, CA, USA, 1987.

51. Rihoux, B. Qualitative and quantitative worlds? A retrospective and prospective view on qualitative comparative analysis. Field Methods 2003, 15. [CrossRef]

52. Oliver, C. Determinants of interorganizational relationships: Integration and future directions. Acad. Manag. Rev. 1990, 15, 241-265. [CrossRef]

53. Benington, J. Partnerships as networked governance? Legitimation, innovation, problem-solving and co-ordination. In Local Partnerships and Social Exclusion in the European Union-New Forms of Local Social Governance; Geddes, M., Benington, J., Eds.; Routledge: London, England, 2001.

54. Dyer, J.H.; Singh, H. The relational view: Cooperative strategy and sources of interorganizational competitive advantage. Acad. Manag. Rev. 1998, 23, 660-679. [CrossRef]

55. Verschoore, J.R.; Balestrin, A. Fatores relevantes para o estabelecimento de redes de cooperação entre empresas do Rio Grande do Sul. Rev. Adm. Contemp. 2008, 12, 1043-1069. [CrossRef]

56. Ireland, R.D.; Hitt, M.A.; Vaidyanath, D. Alliance management as a source of competitive advantage. J. Manag. 2002, 28, 413-446. [CrossRef]

57. Macaulay, C.D.; Richard, O.C.; Peng, M.W.; Hasenhuttl, M. Alliance network centrality, board composition, and corporate social performance. J. Bus. Ethics 2017, 151, 997-1008. [CrossRef]

58. Waddock, S.A.; Graves, S.B. The corporate social performance-financial performance link. Strateg. Manag. J. 1997, 18, 303-319. [CrossRef]

59. Cantele, S.; Zardini, A. Is sustainability competitive advantage for small businesses? An empirical analysis of possible mediators in the sustainability-financial performance relationship. J. Clean. Prod. 2018, 182, 166-176. [CrossRef]

60. Lasker, R.D.; Weiss, E.S.; Miller, R. Partnership synergy: A practical framework for studying and strengthening the collaborative advantage. Milbank Q. 2001, 79, 179-205. [CrossRef] [PubMed]

61. Milwood, P.A.; Roehl, W.S. Orchestration of innovation networks in collaborative settings. Int. J. Contemp. Hosp. Manag. 2018, 30, 2562-2582. [CrossRef]

(C) 2020 by the authors. Licensee MDPI, Basel, Switzerland. This article is an open access article distributed under the terms and conditions of the Creative Commons Attribution (CC BY) license (http://creativecommons.org/licenses/by/4.0/). 